Converts to the Real 



\title{
Converts to the Real
}

CATHOLICISM AND THE MAKING OF CONTINENTAL PHILOSOPHY

\section{Edward Baring}

\author{
III \\ III \\ Harvard University Press
}

Cambridge, Massachusetts

London, England

2019 
Copyright (C) 2019 by the President and Fellows of Harvard College All rights reserved

Printed in the United States of America

\section{First printing}

Cover art: Katie Edwards @ Getty Images

Cover design: Annamarie McMahon Why

$$
\begin{gathered}
9780674238985 \text { (EPUB) } \\
9780674987777 \text { (MOBI) } \\
9780674238978 \text { (PDF) }
\end{gathered}
$$

The Library of Congress has cataloged the printed edition as follows:

Names: Baring, Edward, 1980- author.

Title: Converts to the real : Catholicism and the making of continental philosophy / Edward Baring.

Description: Cambridge, Massachusetts : Harvard University Press, 2019.|

Includes bibliographical references and index.

Identifiers: LCCN 2018041401 | ISBN 9780674988378 (alk. paper)

Subjects: LCSH: Phenomenological theology. | Catholics-Europe-Intellectual

life-2oth century. | Phenomenology. | Philosophy and religion-Europe-History-2oth century.

Classification: LCC B829.5 .B3355 2019 | DDC 142/.7-dc23

LC record available at https://lccn.loc.gov/2018041401 